REPORTS OF MORPHOLOGY
$\begin{gathered}\text { Official Journal of the Scientific Society of Anatomists, } \\ \text { Histologists, Embryologists and Topographic Anatomists } \\ \text { of Ukraine } \\ \text { journal homepage: https://morphology-journal.com }\end{gathered}$

\title{
Morphometric studies of the damaged skin area after experimental thermal trauma and during correction with cryo-lyophilized xenograft skin substrate
}

\author{
Kramar S.B., Volkov K.S., Nebesna Z.M.
}

Ivan Horbachevsky Ternopil State Medical University, Ternopil, Ukraine

\section{ARTICLE INFO}

Received: 3 October, 2018

Accepted: 2 November, 2018

UDC: $616.5-001.17-$

085.324:599.731.1-035.51-076.4]-

092.9

\section{CORRESPONDING AUTHOR}

e-mail: kramar.solomija@gmail.com Kramar S.B.
According to $\mathrm{WHO}$, burns rank third place among other injuries, and in some countries, the second, after traffic injuries. One of the promising tools for treating burn wounds is the use of lyophilized xenograft skin substrate. The purpose of this work was to determine the morphometric parameters of the affected by burns area of the skin in the dynamics after an experimental thermal trauma and in the case of correction by crushed lyophilized xenograft skin substrate. Burning of third degree on the shaved skin of the back of the guinea pig was applied to the vapor under general anesthetic. Morphometrically, at 7 , 14 , and 21 days of the experiment, the thickness of the epidermis (thin skin without a layer of scales), the number of fibroblast cells per unit area, the outer and inner diameter of the capillaries were determined in the boundary and central areas of the wound. Morphometric studies were carried out using programs VideoTest-5.0, KAAPA Image Base and Microsoft Excel on a personal computer. Statistical processing of the obtained quantitative data was carried out using methods of variation statistics with the determination of the mean arithmetic and its error $(M \pm m)$. Student's criterion $(t)$ and reliability index ( $p)$. Differences are considered valid at $p \leq 0.05$. It has been established that already in the 7 day of the experiment, under conditions of wound closure by xenograft skin substrate marked a significant thickening of the epidermis on the periphery of the wound appear. Activation of the process of boundary epithelization contributes to the renewal of components of the microcirculatory bed, the formation of granulation tissue. It was found that on the 14 day of application of the corrective factor in the peripheral zone of the wound, the number of cells of the fibroblast row and the mean value of the thickness of the epidermis reach their peak value, significantly $(p<0.001)$ exceeding such indices of animals in intact group and group of animals without correction. The morphometric parameters of capillaries in this period of the experiment indicate a good development of the microcirculation, which improves regional epithelization. On the 21 day of the experiment, under the condition of correction, the border between the regional and central parts of the wound is almost lost. Thus, the results of morphometric studies indicate that the use of cryo-lyophilized xenograft skin substrate after a thermal trauma of the skin contributes to the healing of the wound defect with the formation of connective tissue of the dermis, angiogenesis, and complete epithelization of the surface of the affected epidermis layer.

Keywords: skin, thermal trauma, cryoliophilized xenodermal substrate, morphometric studies.

\section{Introduction}

Burns are one of the widespread skin damages. The urgency of the problem of thermal damages is determined by the relatively high frequency of their occurrence in everyday life and in the workplace, the severity of the burn disease, the complexity and duration of treatment of such patients, high disability and mortality. In Ukraine, this figure is about 100,000 patients annually $[4,8,11]$.

The term recovery of the burned skin determines the course of burn disease, the formation of complications, the cosmetic effect. It is known that deep and large thermal 
burns are not limited only to local damages of tissues, but also cause significant violations of all systems and organs, metabolic processes in the body [1, 2, 4, 6]. The primary link in the pathogenesis of burn disease is the destruction of the skin, significant hemodynamic disorders and violation of neuroendocrine regulation $[6,12,14]$.

In the case of wounds occurrence, the main task is to eliminate the defect in order to restore the integrity of tissues, through reparative regeneration [5]. In recent years, one of the new directions in the treatment of wound process is the creation and application of biologically active covers that can release biologically active substances that affect the reparative processes $[5,10,18,21]$.

A number of scientific studies have shown [4, 8, 11, 19] that the use of lyophilized xenograft skin is promising in the treatment of the burned organism, but studies on the use of its crushed substrate, after the early necrectomy of the affected areas, are still insufficient. It is established that it possesses high sorption-antitoxic, metabolic, plastic and oxidative-reduction potentials, and is available as a tablet formulation containing biologically active compounds rich in amino acids and trace elements [9]. However, the morphological features of healing of thermal wounds during its use remain little studied.

Taking into account the above, the purpose of this work was to establish the morphometric parameters of the affected by burns area of the skin in the dynamics after an experimental thermal trauma and under conditions of correction by crushed lyophilized xenograft skin substrate.

\section{Materials and methods}

Experimental studies were performed on 42 sexually mature guinea pigs. In conducting research, the international rules and principles of the "European Convention for the Protection of Vertebrate Animals used for Experiments and for Other Scientific Purposes" (Strasbourg, 1986) and "General Ethical Principles of Animal Experiments" (Kyiv, 2001) have been respected.

Experimental animals were divided into three groups: intact guinea pigs; animals with severe thermal trauma; animals with burn injury, which, after the early necrectomy of damaged tissues, were covered with crushed cryolyophilized xenograft skin substrate.

The burning of the third degree on the shaved surface of the skin of the animal's back was applied by water vapor at a temperature of $96-97^{\circ} \mathrm{C}$ for 60 seconds under general anesthetic. The size of the damages was $18-20 \%$ of the body surface.

To investigate the features of morphometric changes in the skin after burn injury, the animals were decapitated using a guillotine under general, etheric anesthesia at 7 , 14 and 21 days of the experiment, which corresponds to the stages of early and late toxemia and septicotoxemia of the burn disease [4]. Animals of the third experimental group after a thermal trauma after 1 day of the experiment performed an early necrectomy of damaged tissue followed by wound closure by the cryo-lyophilized xenograft skin substrate. Therefore, the removal of animals from the experiment and the study of the morphometric state of the skin in the central and marginal areas of the wound was carried out at 7, 14 and 21 days after burning.

The material was collected for microscopic studies in accordance with the generally accepted method $[7,16]$. Sections of the skin from the central and marginal part of the wound were fixed in $10 \%$ formalin solution. Dehydration of the material was carried out in alcohols of increasing concentration in a machine for histological processing of tissues AT-4, poured in paraffin blocks. The received on the snuff-microtome MS-2 sections of 5-6 microns thickness were stained with hematoxylin and eosin.

Morphometric studies were performed using a system of visual analysis of histological preparations. The images were taken to a computer monitor using microscope MICROmed SEO SASAN with Vision CCD Camera. Morphometric studies were carried out using programs VideoTest-5.0, KAAPA Image Base and Microsoft Excel on a personal computer. The research was carried out at definite dates of the experiment on preparations painted with hematoxylin and eosin. Morphometrically in the boundary and central areas of the wound, the thickness of the epidermis (thin skin without a layer of scales), the number of fibroblast cells per unit area, the outer and inner diameter of the capillaries were determined.

The number of fibroblast cells per unit area was determined by the formula:

$N_{f}=\Sigma_{f} / S_{d}$

where $N_{f}$ - number of fibroblasts per unit area $\left(1 \mathrm{~mm}^{2}\right)$, $\Sigma_{f}$ - total number of fibroblasts, $S_{d}$ - area of the dermis.

Statistical processing of the obtained quantitative data was carried out using methods of variation statistics with the determination of the mean arithmetic and its error $(M \pm m)$, Student's criterion $(t)$ and reliability index $(p)$. Differences are considered valid at $p \leq 0.05$.

\section{Results}

The healing of a wound defect after a thermal injury to the skin is accompanied by compensatory restoration of its undamaged sites, especially the perifocal zone, therefore the morphometric changes of not only the center of the defeat, but also its periphery were investigated.

Table 1 shows the quantitative parameters of the studied parameters in all terms of the experiment.

It has been established that at application of lyophilized xenograft skin substrate on 7 day of the experiment in the marginal zone of the wound marked significant thickening of the epidermis. Morphometrically it was found that the average value of its thickness is $(83.23 \pm 2.86) \mu \mathrm{m}$, which significantly $(p<0.01)$ exceeds the data of group II of animals in 1.16 times, and the index of intact group of animals in 1.58 times $(p<0.001)$ (see Table 1). The number of cells of the fibroblast row in this zone is significantly growing $(p<0.001)$, with an average value of $(2107 \pm 27)$ cells $/ \mathrm{mm}^{2}$, 
Table 1. Morphometric parameters of the structural components of the skin of animals at different terms after a thermal trauma and under conditions of use of lyophilized xenograft skin substrate.

\begin{tabular}{|c|c|c|c|c|c|c|}
\hline \multirow{2}{*}{\multicolumn{3}{|c|}{ The terms of the experiment }} & \multicolumn{4}{|c|}{ Parameters $(\mathrm{M} \pm \mathrm{m})$} \\
\hline & & & $\begin{array}{l}\text { Thickness of the } \\
\text { epidermis, } \\
\mu \mathrm{m}\end{array}$ & $\begin{array}{c}\text { The number of } \\
\text { fibroblastic series cells, } \\
\text { cells } / \mathrm{mm}^{2}\end{array}$ & $\begin{array}{c}\text { External diameter of } \\
\text { hemocapillars, } \\
\mu \mathrm{m}\end{array}$ & $\begin{array}{c}\text { Diameter of } \\
\text { hemocapillaries lumen, } \\
\mu \mathrm{m}\end{array}$ \\
\hline \multicolumn{3}{|c|}{ Intact } & $52.54 \pm 2.03$ & $1432 \pm 31$ & $8.022 \pm 0.391$ & $6.052 \pm 0.373$ \\
\hline \multirow{6}{*}{ Burn } & \multirow{2}{*}{7 day } & MAW & $71.69 \pm 2.48^{* * *}$ & $1035 \pm 26$ *** & $11.97 \pm 0.31$ *** & $8.353 \pm 0.261^{* * *}$ \\
\hline & & CAW & - & $268.3 \pm 18.1^{* * *}$ & $14.46 \pm 0.24^{* * *}$ & $11.84 \pm 0.16^{* * *}$ \\
\hline & \multirow{2}{*}{14 day } & MAW & $80.45 \pm 3.07^{* * *}$ & $1607 \pm 34^{* * *}$ & $10.75 \pm 0.34^{* * *}$ & $7.811 \pm 0.211^{* * *}$ \\
\hline & & CAW & $18.52 \pm 2.33^{* * *}$ & $439.2 \pm 21.1^{* * *}$ & $6.163 \pm 0.172$ *** & $5.051 \pm 0.140$ * \\
\hline & \multirow{2}{*}{21 day } & MAW & $85.38 \pm 2.69 * * *$ & $1750 \pm 34$ *** & $10.56 \pm 0.13^{* * *}$ & $7.833 \pm 0.172$ *** \\
\hline & & CAW & $25.45 \pm 2.08$ *** & $610.2 \pm 23.2$ *** & $6.751 \pm 0.132$ ** & $5.011 \pm 0.143$ * \\
\hline \multirow{6}{*}{ Correction } & \multirow{2}{*}{7 day } & MAW & $83.23 \pm 2.86$ ***/\#\# & 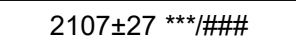 & $10.84 \pm 0.11^{* * * / \# \#}$ & $8.094 \pm 0.092$ *** \\
\hline & & CAW & - & 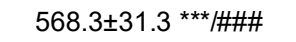 & $11.04 \pm 0.16^{* * *} / \# \# \#$ & $8.564 \pm 0.123^{* \star \star} / \# \# \#$ \\
\hline & \multirow{2}{*}{14 day } & MAW & $141.3 \pm 4.6^{* * *} / \# \# \#$ & 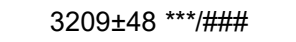 & $10.65 \pm 0.13^{* * *}$ & $7.831 \pm 0.151^{\star * *}$ \\
\hline & & CAW & $48.74 \pm 1.53 \# \# \#$ & 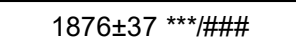 & $8.322 \pm 0.121 \# \# \#$ & $6.893 \pm 0.114$ */\#\#\# \\
\hline & \multirow{2}{*}{21 day } & MAW & 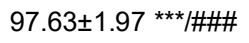 & $2487 \pm 33^{\star \star *} / \# \# \#$ & $8.931 \pm 0.111$ */\#\#\# & $7.272 \pm 0.142^{* *} / \#$ \\
\hline & & CAW & $71.25 \pm 2.07$ ***/\#\#\# & $1761 \pm 19$ ***/\#\#\# & $8.542 \pm 0.113 \# \# \#$ & $6.321 \pm 0.093 \# \# \#$ \\
\hline
\end{tabular}

Notes: * - values that are statistically significantly different from those of an intact group of animals $\left({ }^{*}-p<0.05 ;{ }^{* *}-p<0.01 ;{ }^{* * *}-p<0.001\right)$; $\#$ - values that are statistically significantly different from those of a group of animals with a burn (\# - $p<0.05 ; \# \#-p<0.01$; \#\# - $p<0.001)$; MAW - marginal area of the wound; CAW - central area of the wound.

which is 1.47 and 2.04 times, respectively, exceeds the I and II experimental groups of animals.

The morphometric investigations of the area of the damage in this period of the experiment have established that the average value of the number of cells of the fibroblast row per unit area is $(568.3 \pm 31.3)$ cells $/ \mathrm{mm}^{2}$, which is significantly $(p<0.001)$ higher than the group of animals without correction in 2.12 times, but significantly $(p<0.001)$ is less than that data of animals of group I - in 2.52 times (see Table 1). The mean value of the diameter of the blood capillaries in this zone is $(11.04 \pm 0.16) \mu \mathrm{m}$ and the average diameter of their lumen is $(8.564 \pm 0.123) \mu \mathrm{m}$, which is significantly $(p<0.001)$ lower than II groups of animals in 1.31 and 1.38 times respectively. However, these indices are significantly higher $(p<0.001)$ in comparison with the intact group of animals, because parameters of not only newly created hemocapillars, but also of stored vasodilated vessels in the central zone of the wound are measured morphometrically.

Morphometrically, it was found that on the 14 day of the experiment, using the corrective factor in the peripheral regions of the wound, the epidermis was thickened, its average value was $(141.3 \pm 4.6) \mu \mathrm{m}$, which significantly $(p<0.001)$ exceeds the intact group of animals and animals with burning injury and without correction is 2.69 and 1.76 times respectively (see Table 1).

In the dermis of the perifocal area there is an intensive increase in the number of cells of the fibroblastic row, whose average value is $(3209 \pm 48)$ cells $/ \mathrm{mm}^{2}$ and significantly $(p<0.001)$ exceeds such an indicator of animals of the I and II experimental groups at 2.24 and 2.00 times respectively (see Table 1 ).

In the peripheral zones, wounds on the 14 day after a thermal trauma under conditions of correction microscopically marked expanded vessels of the microcirculatory bed, the morphometric parameters of which are: the outer diameter - $(10.65 \pm 0.13) \mu \mathrm{m}$, the diameter of the lumen - $(7,831 \pm 0,151) \mu \mathrm{m}$ and with $a$ confidence $p<0.001$ exceed these parameters of animals of the intact group. While in the healing zone of the wound, the average values of the outer and inner diameters of the blood capillaries are respectively $(8,322 \pm 0,121) \mu \mathrm{m}$ and $(6,893 \pm 0,114) \mu \mathrm{m}$. At the same time, the average value of the outer diameter does not significantly differ from the indicator of the group of intact animals, and the internal one - exceeds the norm index by 1.14 times $(p<0.05)$ (see Table 1).

Microscopically, during this experiment period, a young granulation tissue that is rich in cells of the fibroblastic series with a mean density of $(1876 \pm 37)$ cells $/ \mathrm{mm}^{2}$, which significantly $(p<0.001)$ exceeds such an indicator of groups I and II, is well expressed in the area of burn wound. respectively 1.31 and 4.27 times. At 14 day of the experiment under conditions of crushed cryo-lyophilized xenograft skin substrate, the mean value of the thickness of the epidermal regenerate over the granulation tissue is $(48.74 \pm 1.53) \mu \mathrm{m}$ and significantly $(p<0.001)$ exceeds the II experimental group of animals at 2.63 times (see Table 1).

On the 21 day of the application of the corrective factor, it was morphometrically determined that the mean value of 
the thickness of the epidermis in the healing area is $(71.25 \pm 2.07) \mu \mathrm{m}$, which is significantly $(p<0.001)$ higher than the values of the I and II experimental groups of animals at 1.36 and 2.80 times respectively. In the perifocal zone of the wound, in comparison with the previous term of the experiment, the thickness of the epidermis from which the epidermal regenerate starts are reduced by 1.45 times, but it remains significantly $(p<0.001)$ greater in 1.86 and 1.14 times than the corresponding indices of the intact group animals and animals with a burn injury and without the use of corrective factors (see Table 1).

According to the results of morphometric studies, the average value of the number of fibroblasts in the border zone of the healing zone is reduced by 1.29 times compared with the previous trial, however, it remains significantly $(p<0.001)$ greater in 1.74 and 1.42 times than for the corresponding values of this parameter of the group intact animals and animals with burn injury and without correction (see Table 1). In the central zone of the wound, the average value of the number of these cells per unit area is $(1761 \pm 19)$ cells $/ \mathrm{mm}^{2}$, which significantly $(p<0.001)$ exceeds the indicators of groups I and II in animals at 1.23 and 2.89 times respectively (see Table 1 ).

At the periphery of the healing area according to the morphometric studies, the average value of the outer diameter of the capillaries is equal to $(8,931 \pm 0,111) \mu \mathrm{m}$, and the inner - $(7,272 \pm 0,142) \mu \mathrm{m}$, which is significantly lower than the animals' of experimental group, respectively, in $1.18(p<0.001)$ and $1.07(p<0.05)$ times (see Table 1).

In the center of the damaged area at 21 day of application of the corrective factor, there is a presence in the papillary region of the dermis of newly formed hemocapillaries, whose endothelial cells have large nuclei and an enlarged cytoplasmic zone. The average value of the outer diameter of these vessels is $(8,542 \pm 0,113) \mu \mathrm{m}$, and the average value of the diameter of the lumen is $(6,321 \pm 0,093) \mu \mathrm{m}$, which does not significantly differ from the corresponding morphometric indices of animals intact group (see Table 1).

The dynamics of changes in the thickness of the epidermis and the density of fibroblasts per unit area is illustrated in Figures 1 and 2, respectively.

\section{Discussion}

Morphometric and quantitative research methods, which give an opportunity to more objectively evaluate the morphofunctional state of histological structures in the normal way, as well as to detect patterns of compensatory, adaptive, destructive and regenerative processes [3], take an important place among morphological investigations.

It is known that healing of the wound defect is accompanied by compensatory reconstruction of the preserved areas of the skin, especially of perifocal zone [6, $13,20]$. However, for today the features of remodeling of structural components of the skin of the marginal region of the wound have not been sufficiently studied, therefore

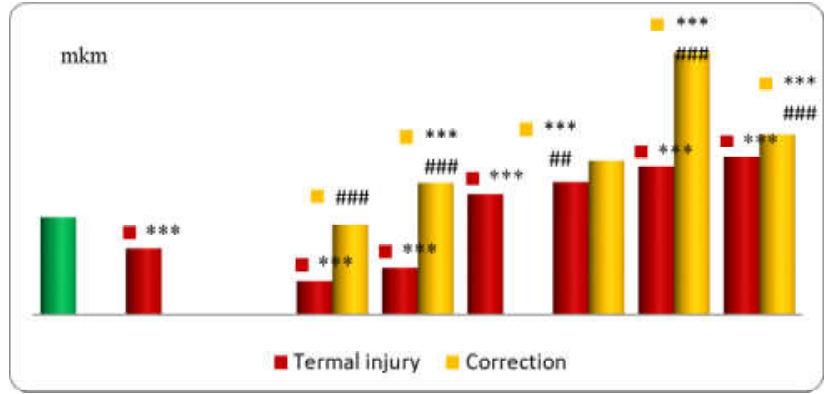

Fig. 1. Dynamics of thickness changes in the epidermis of the marginal and central zones of the animals skin after thermal injury and under correction conditions. ${ }^{*}$ - values that statistically significantly differ from the indicators of the intact group of animals $\left({ }^{* * *}-p<0.01\right)$; \# - values that statistically significantly differ from the indicators of the group of animals with a burn (\#\#-p<0.01; \#\# $-p<0.001)$.

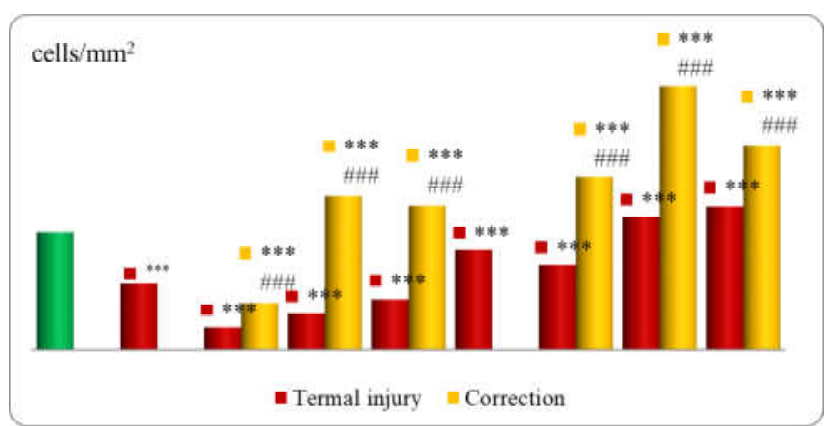

Fig. 2. Dynamics of changes in the number of fibroblasts of the marginal and central zones of the animals skin after thermal injury and under correction conditions. * - values that statistically significantly differ from the indicators of the intact group of animals $\left.{ }^{* * *}-p<0.001\right)$; \# - values that statistically significantly differ from the indicators of the group of animals with a burn (\#- $p<0.01$; \#\# $-p<0.001)$.

morphometric changes not only of the center of the damage, but also of its periphery were not investigated.

The performed morphometric studies have found that already in the early term of the experiment ( 7 day), under conditions of wound closure by xenodermal substrate marked a significant thickening of the epidermis on the periphery of the wound due to an increase in the mitotic activity of the cells of the germ layer (see Fig. 1). Activation of the boundary epithelization process promotes the renewal of the components of the microcirculatory bed, the formation of granulation tissue [18, 20].

It is common knowledge that the largest population of cells of the connective tissue base of the skin are fibroblasts that produce, renew the components of the intercellular substance, participate in wound healing, regulate inflammation, differentiate keratinocytes, processes of cellular interactions, and stimulate angiogenesis [15, 21, 23]. Some authors have already established [17, 20, 21, 22,23 ] that they are involved in the formation of granulation tissue with a burn injury; migrate to the site of defeat and synthesize the components of the intercellular matrix, which promotes the involvement of macrophages, neutrophils in 
the wound process; produce metal proteases, a number of cytokines, growth factors that stimulate other cells prior to migration and proliferation. Therefore, at day 7 of the experiment, under the conditions of correction in the peripheral area of the wound, the number of fibroblasts per unit area increased by 1.47 times compared to the rate of intact animals and by 2.04 times compared with the animals of the second group (see Fig. 2). The established morphometric indices of structural components of the skin indicate the activation of reparative processes already in the early term of the experiment.

According to morphometric studies, at 14 day of application of the corrective factor in the peripheral zone of the wound, the number of cells of the fibroblast number and the mean thickness of the epidermis reach their peak value, significantly $(p<0.001)$ exceeding such indices of animals of the intact group and group of animals without correction (see Fig. 1, 2). The morphometric parameters of the capillaries in this period of the experiment indicate good development of the microcirculatory bed, which, in turn, improves regional epithelization (see Table 1) [15, 24].

At the 21 day of the experiment in animals of the third group, the border between the regional and central parts of the wound is almost lost. In the perifocal region of the damage, in comparison with the previous trial, the mean thickness of the epidermis from which the epidermal regenerate starts are reduced by 1.45 times, due to the moderate mitotic activity of the keratinocytes and the healing of the wound defect at that time (see Fig. 1). In the central area, the number of fibroblast cells per unit area is significantly $(p<0.001)$ higher than the intact group of animals in 1.23 times and 2.89 times the rate of animals with thermal trauma without correction (see Fig. 2). Morphometric parameters of hemocapillaries are not significantly different from those of intact animals. the amount per unit area is significantly $(p<0.001)$ higher than

\section{References}

[1]Adeloye, D., Bowman, K., Chan, K. Y., Patel, S., Campbell, H., \& Rudan, I. (2018). Global and regional child deaths due to injuries: an assessment of the evidence. J. Glob. Health, 8(2), 021104. doi: 10.7189/jogh.08.021104.

[2] Andrade, P., Kaura, A. S., Bryant, J. R., \& Burke, E. (2018). Thermal Burn Injury from a Wedding Ring: An Unusual Case. J. Am. Coll. Clin. Wound Spec., 9(1-3), 32-34. doi: 10.1016/ j.jccw.2018.06.004

[3] Avtandilov, H. H. (2002). Basics of quantitative pathological anatomy. Moskow: Medicine.

[4] Bihuniak, V. V., \& Povstianyi, M. Yu. (2004). Termal injury. Ternopil: Ukrmedknuha.

[5] Han, C. M., Yu, M. R., \& Wang, X. G. (2018). Summary of advances in the research of wound therapy. Zhonghua Shao Shang Za Zhi., 34(12), 864-867. doi: 10.3760/cma.j.issn.10092587.2018.12.009.

[6] Hanglin, Ye., \& Suvranu, D. (2017). Thermal injury of skin and subcutaneous tissues: A review of experimental approaches and numerical models. Burns, 43(5), 909-932. doi:10.1016/ j.burns.2016.11.014. the intact group of animals in 1.23 times and 2.89 times the rate of animals with thermal trauma without correction (see Table 1).

Obtained new scientific results reveal the peculiarities of morphometric changes in the skin during severe thermal trauma and the application of cryo-lyophilized xenograft skin substrate, which is theoretical and practical ground for the development of adequate methods for correction of the effects of thermal trauma.

\section{Conclusions}

1. Morphometrically it was found that the application of crushed cryo-lyophilized xenograft skin substrate to the wound that was formed after the necrectomy of the thermally damaged areas already in the early period after burn ( 7 day) activates regenerative processes. There is a formation of epithelial regenerate in the marginal region of the wound, whose thickness is significantly $(p<0.01)$ exceeding the data of the group of animals without correction in 1.16 times, and the data of intact group of animals in 1.58 times $(p<0.001)$. In the affected area, granulation tissue is saturated with fibroblasts, the number of which is significantly $(p<0.001)$ exceeding the indicator of a group of animals without correction in 2.12 times.

2. In late terms (14, 21 days), the positive effect of using cryo-lyophilized xenograft skin substrate after an experimental thermal trauma is manifested by healing of the wound defect with the formation of connective tissue of the dermis, in which the number of fibroblasts increases and reliably $(p<0.001)$ exceeds the indicator of the group of animals without correction in 2.89 times. An active course of angiogenesis and complete epithelization of the surface of the damage with an epidermal layer is set, whose thickness is significantly $(p<0.001)$ exceeds the indicator of a group of animals with burn injury without correction in 2.80 times.

[7] Horalskyi, L. P., Khomych, V. T., \& Kononskyi, O. I. (2005). Fundamentals of histological technology and morphofunctional methods of research in norm and in pathology. Zhytomyr: Polissia.

[8] Huda, N. V., \& Bihuniak A. V. (2007). The usege of lyophilized xenoderm transplantants for the treatment of derma burns in the elderly. Hospital surgery, 3, 81-83.

[9] Huda, N. V., \& Tsymbaliuk, A. V. (2012). Content of aminoacids and microelements in crioliofilized xenoskin as an indicator of its biological activity. Medical chemistry, 14(1), 50, 70-72.

[10] John, P. A., John, S., John, G., Sparrow, E., \& Minkowycz, W. J. (2018). Tissue burns due to contact between a skin surface and highly conducting metallic media in the presence of intertissue boiling. Burns. https://doi.org/10.1016/ j.burns.2018.09.010

[11] Kovalchuk, A. O., \& Piatkovskyi, T. I. (2010). Dynamical changes of results of experimental burn wounds after early necrectomy using lyophilized xenodermotransplants of secondary cutting. Reports of scientific researches, 2, 46-49.

[12] Lee, J. H., Kim, J. W., Lee, J. H., Chung, K. J., Kim, T. G., Kim, Y. 
H., \& Kim, K. J. (2018). Wound healing effects of paste type acellular dermal matrix subcutaneous injection. Arch Plast Surg., 45(6), 504-511. doi: 10.5999/aps.2018.00948.

[13] Leszczynska, A., Kulkarni, M., Ljubimov, A. V., \& Saghizadeh, M. (2018). Exosomes from normal and diabetic human corneolimbal keratocytes differentially regulate migration, proliferation and marker expression of limbal epithelial cells. Sci. Rep., 8(1), 15173. doi: 10.1038/s41598-018-33169-5.

[14] Liu, Y. C., Ang, H. P., Teo, E. P., Lwin, N. C., Yam, G. H., \& Mehta, J. S. (2016). Wound healing profiles of hyperopicsmall incision lenticule extraction (SMILE). Sci. Rep., 6, 29802. doi: $10.1038 /$ srep29802.

[15] Miadelets, O. D., \&Adaskevich, V. P. (2006). Morphofunctional dermatology. Moskow: Medlit.

[16] Sarkisov, D. S., \& Perova, Yu. L. (1996). Microscopic technique. Moskow: Medcine.

[17] Sarrazy, V., Billet, F., Micallef, L., Coulomb, B., \& Desmouliere, A. (2011). Mechanisms of pathological scarring: Role of myofibroblasts and current developments. Wound Repair and Regeneration, 19 (1), 10-15. doi: 10.1111/j.1524475X.2011.00708.x.

[18] Smeringaiova, I., Reinstein Merjava, S., Stranak, Z., Studeny, P., Bednar, J., \& Jirsova, K. (2018). Endothelial Wound Repair of the Organ-Cultured Porcine Corneas. Curr. Eye Res., 43(7),
856-865. doi: 10.1080/02713683.2018.1458883.

[19] Viter, V. S. (2014). Ultrastructural state of muscular tunic of the heart after experimental thermal injury in applying lyophilized xenografts. Nauka i Studia, 8 (118), 107-111.

[20] Willenborg, S., \& Eming, S. A. (2018). Cellular networks in wound healing. Science, 362 (6417), 891-892. doi: 10.1126/ science.aav5542.

[21] Woodley, D. T. (2017). Distinct Fibroblasts in the Papillary and Reticular Dermis: Implications for Wound Healing. Dermatol. Clin., 35(1), 95-100. doi: 10.1016/j.det.2016.07.004.

[22] Xiao, W., Tang, H., Wu, M., Liao, Y., Li, K., Li, L., \& Xu, X. (2017). Ozone oil promotes wound healing by increasing the migration of fibroblasts via PI3K/Akt/mTOR signaling pathway. Biosci. Rep., 37(6). pii: BSR20170658. doi: 10.1042/ BSR20170658.

[23] Yoon, D., Yoon, D., Sim, H., Hwang, I., Lee, J. S., \& Chun, W. (2018). Accelerated Wound Healing by Fibroblasts Differentiated from Human Embryonic Stem Cell-Derived Mesenchymal Stem Cells in a Pressure Ulcer Animal Model. Stem Cells Int., 30, 4789568 doi: 10.1155/2018/4789568

[24] Zviahintseva, T. V., Hrun, V. V., \& Naumova, O. V. (2013). Morphological changes in the skin of guinea pigs after local ultraviolet irradiation with the use of drugs with photoprotective activity. Medicine today and tomorrow, 58(1), 59-63.

\section{МОРФОМЕТРИЧНІ ДОСЛІДЖЕННЯ УШКОДЖЕНОЇ ДІЛЯНКИ ШКІРИ ПІСЛЯ ЕКСПЕРИМЕНТАЛЬНОЇ ТЕРМІЧНОЇ ТРАВМИ ТА} ЗА УМОВ КОРЕКЦІЇ КРІОЛІОФІЛІЗОВАНИМ КСЕНОДЕРМАЛЬНИМ СУБСТРАТОМ

\section{Крамар С.Б., Волков К.С., Небесна З.М.}

За даними ВООЗ опіки посідають третє місце серед інших травм, а в деяких країнах - друге, поступаючись лише транспортному травматизму. Одним із перспективних засобів у лікуванні опікової рани є використання ліофрілізованого ксенодермального субстрату. Метою цієї роботи було встановлення морфометричних параметрів ураженої опіком ділянки шкіри в динаміці після експериментальної термічної травми та за умов корекції подрібненим субстратом ліофрілізованої ксеношкіри. Опік III ступеня наносили водяною парою під загальним ефрірним наркозом на епільовану поверхню шкіри спини морської свинки. Морфометрично на 7, 14 та 21 доби досліду у крайовій та центральній ділянках рани визначали товщину епідермісу (тонкої шкіри без шару рогових лусочок), кількість клітин фібробластичного ряду на одиницю площі, зовнішній та внутрішній діаметри капілярів. Морфометричні дослідження проводили за допомогою програм ВидеоТест-5.0, КАAPA Image Base ma Microsoft Excel на персональному комп'ютері. Cтатистичну обробку отриманих кількісних даних проводили за допомогою методів варіаційної статистики з визначенням середньої арифметичної величини та ї̈ похибки (М士m), критерію Стьюдента (t) та показника достовірності (p). Достовірними вважаються відмінності при $p \leq 0,05$. Встановлено, що вже на 7 добу досліду в умовах закриття рани ксенодермальним субстратом відмічається суттєве потовщення епідермісу на перифрерії рани. Активації процесу крайової епітелізації сприяє оновлення компонентів мікроциркуляторного русла, утворення грануляційної тканини. З'ясовано, що на 14 добу застосування коригуючого чинника у периферійній зоні рани кількість клітин фрібробластичного ряду та середнє значення товщини епідермісу сягають свого пікового значення, достовірно $(p<0,001)$ перевищуючи такі показники тварин інтактної групи та групи тварин без корекції. Морфометричні параметри капілярів у цей термін досліду свідчать про добру розвиненість мікроциркуляторного русла, що покращує крайову епітелізацію. На 21 добу досліду за умов корекції майже втрачається межа між крайовою та центральними ділянками рани. Таким чином, результати морфометричних досліджень свідчать, що використання кріоліофрілізованого ксенодермального субстрату після термічної травми шкіри сприяє загоєнню раневого дефекту з утворенням сполучної тканини дерми, ангіогенезом та повною епітелізацією поверхні ураження епідермальним пластом.

Ключові слова: шкіра, термічна травма, кріоліофрілізований ксенодермальний субстрат, морфометричні дослідження.

\section{МОРФОМЕТРИЧЕСКИЕ ИССЛЕДОВАНИЯ ПОВРЕЖДЕННОГО УЧАСТКА КОЖИ ПОСЛЕ ЭКСПЕРИМЕНТАЛЬНОЙ ТЕРМИЧЕСКОЙ ТРАВМЫ И ПРИ КОРРЕКЦИИ КРИОЛИОФИЛИЗИРОВАННЫМ КСЕНОДЕРМАЛЬНЫМ СУБСТРАТОМ} Крамар С.Б., Волков К.С., Небесная 3.М.

По данным ВОЗ ожоги занимают третье место среди других травм, а в некоторых странах - второе, уступая лишь транспортному травматизму. Одним из перспективных средств в лечении ожоговой раны является использование лиофилизированного ксенодермального субстрата. Целью этой работы было установление морфометрических параметров участка кожи, поврежденного ожогом, в динамике после экспериментальной термической травмы и в условиях коррекции измельченным субстратом лиофилизированной ксенокожи. Ожог III степени на эпилированную поверхность кожи спины морской свинки наносили водяным паром под общим эфрирным наркозом. Морфометрически на 7, 14 и 21 сутки опыта в краевом и центральном участках раны определяли толщину эпидермиса (тонкой кожи без слоя роговых чешуек), количество клеток фибробластического ряда на единицу площади, внешний и внутренний диаметры капилляров. Морфрометрические исследования проводили с помощью программ BuдеоTест-5.0, Kaаpe Image Base и Microsoft Excel на персональном 
компьютере. Статистическую обработку полученных количественных данных проводили с помощью методов вариационной статистики с определением средней арифметической величины и ее погрешности $(M \pm m)$, критерия Стьюдента $(t)$ u

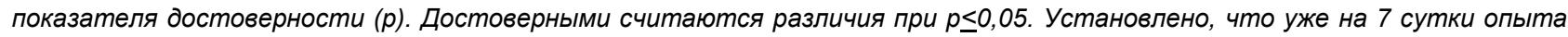
в условиях закрытия раны ксенодермальным субстратом отмечается существенное утолщение эпидермиса на периферии раны. Активации процесса краевой эпителизации способствует обновление компонентов микроциркуляторного русла, образование грануляционной ткани. Выяснено, что на 14 сутки применения корректирующего фрактора в периферической зоне раны количество клеток фрибробластического ряда и среднее значение толщины эпидермиса достигают своего пикового значения, достоверно ( $<<0,001)$ превышая такие показатели животных интактной группы и группы животных без коррекции. Морфометрические параметры капилляров в этот срок опыта свидетельствуют о хорошей развитости микроциркуляторного русла, что улучшает краевую эпителизацию. На 21 сутки опыта в условиях коррекции практически стирается грань между краевым и центральным участками раны. Таким образом, результаты морфометрических исследований свидетельствуют, что использование криолиофилизованного ксенодермального субстрата после термической травмы кожи способствует заживлению раневого дефректа с образованием соединительной ткани дермы, ангиогенезом и полной эпителизацией поверхности поражения эпидермальным пластом.

Ключевые слова: кожа, термическая травма, криолиофилизированный ксенодермальный субстрат, морфрометрические исследования. 